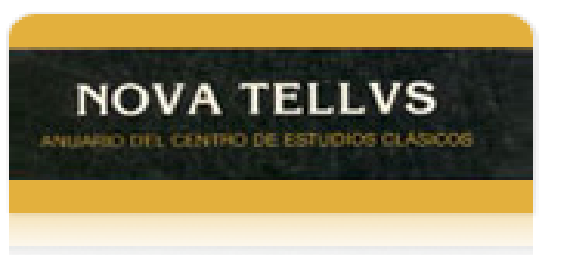

Nova Tellus

ISSN: 0185-3058

novatelu@servidor.unam.mx

Centro de Estudios Clásicos

México

García Pérez, David

Persuasión, catarsis y lo sublime: procedimientos retóricos del texto literario

Nova Tellus, vol. 31, núm. 2, 2014, pp. 25-41

Centro de Estudios Clásicos

Distrito Federal, México

Disponible en: http://www.redalyc.org/articulo.oa?id=59137773002

- Cómo citar el artículo

- Número completo

- Más información del artículo

- Página de la revista en redalyc.org

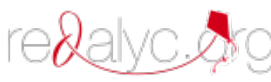

Sistema de Información Científica

Red de Revistas Científicas de América Latina, el Caribe, España y Portugal

Proyecto académico sin fines de lucro, desarrollado bajo la iniciativa de acceso abierto 


\title{
Persuasión, catarsis y lo sublime: procedimientos retóricos del texto literario
}

Persuasion, Catharsis and the Sublime:

Rhetorical Procedures of the Literary Text

\author{
David GARCía PÉREZ \\ Universidad Nacional Autónoma de México \\ prometeo9@att.net.mx
}

\begin{abstract}
RESUMEN: Se presenta un análisis en el que se definen y comparan los términos de persuasión, catarsis y lo sublime con el fin de establecer algunas pautas de interpretación acerca del texto literario; para ello se atienden básicamente los siguientes tratados: Retórica y Poética de Aristóteles, así como el De lo sublime del pseudo Longino.
\end{abstract}

\begin{abstract}
This paper presents an analysis defining and comparing terms as persuasion, catharsis and the sublime, in order to offer some guidelines for interpretation of the literary text. For this purpose we appeal to the following the treaties: Rhetorics and Poetics by Aristotle, as well as On the Sublime by pseudo Longinus.

PALABRAS ClAVE: Aristóteles, catarsis, persuasión, pseudo Longino, sublime, análisis literario.

KEY WORDS: Aristotle, catharsis, persuasion, pseudo Longinus, sublime, literary analysis.

RECIBIDO: 17 de septiembre de 2013 • ACEPTADO: 11 de marzo de 2014.
\end{abstract}

La poesía griega antigua en sus tres géneros, épica, lírica y dramática, estaba imbuida en una tradición musaica: eran las deidades quienes cantaban los avatares de los héroes a través del poeta, según Homero ${ }^{1}$ o bien, le enseñaban a éste el arte de la poesía para que pudiera edificar los versos, ${ }^{2} \mathrm{o}$ lo poseía la divinidad para que tuviera la capacidad de expresar los contenidos de la palabra, como se puede colegir del entusiasmo poético de algunos líricos como Arquíloco, Safo y Alceo. Siendo esto así, la recepción de la poesía operaba diversos efectos y reacciones que ya desde la antigüedad se trataron de definir por varios caminos, de acuerdo con el texto y su contexto en cuestión. La manera en la que el poeta presentaba sus versos era de suma relevancia para establecer un vínculo con el receptor, pues éste la percibiría según la intención, los fines y el interés del emisor. Los proemios de la poesía homérica invocan a las Musas para que sean ellas quienes canten ya la cólera de Aquiles, ya el catálogo de las naves, ya las aventuras

\footnotetext{
${ }^{1}$ Hom., Il., I, 1-2; II, 484-487; Od., I, 1-2.

${ }^{2}$ Hes., Theog., 1-11; 22-23.
} 
de Odiseo. Son las Musas quienes cantan y Homero es su transmisor, un intermediario entre ellas y los oyentes. Esta particularidad no es un simple lugar común: es una fórmula compleja que construye la relación comunicativa entre poeta y receptor. Éste vería en aquél a un portavoz sagrado, el divino Homero, que conducía la palabra de las Musas a los humanos oídos. Hesíodo, por su parte, se presenta como alumno de tales divinidades y esto lo convertía, a su vez, en maestro de quienes lo escuchaban, de ahí el carácter didascálico de su poesía; ${ }^{3}$ y los poetas líricos, por otro lado, tenían en distintos dioses un motor de inspiración o de auxilio para los motivos expresados a través de sus versos. Incluso en la tragedia, a pesar de que en ella no existe propiamente una invocación a la divinidad, la organización de las Grandes Dionisias coloca como dios espectador, en primer lugar, a Dioniso:

En la cultura preplatónica, la inspiración divina valía tanto para garantizar la credibilidad del poeta como para respaldar su habilidad técnica: un cantor podía ufanarse de su propia pericia compositiva y proclamarse, al mismo tiempo, inspirado por los dioses. ${ }^{4}$

Si lo anterior es así, cabe preguntarse, sobre la base estricta de lo que hoy se conoce como texto literario, cuáles son los procedimientos retóricos que permiten acercarse a una comprensión de conceptos como la persuasión, la catarsis y lo sublime, en tanto que expresiones de la recepción poética y sus efectos. Para ello, son de capital importancia la Retórica y Poética de Aristóteles, así como el tratado De lo sublime atribuido a Longino, pero se acude también a otras fuentes que refuerzan el análisis propuesto.

En efecto, en Las ranas de Aristófanes se puede hallar por primera vez de modo amplio y bien definido un testimonio que juzgó "literariamente" el arte de la poesía, de la tragedia en particular, y con ello estableció el canon de los tres trágicos: Esquilo, Sófocles y Eurípides, además de indicar las razones de ello. Si se trae a colación esta comedia es porque en ella se entreveran aspectos de juicio poético que responden a una forma de recepción propia de los antiguos griegos de época clásica, y de la cual Aristófanes hace eco, y que debía responder más ampliamente al gusto de la poesía trágica y a la educación vigente de ese momento. Pues bien, uno de los elementos que ahí el poeta cómico toma en cuenta para reseñar la tragedia griega del siglo v a. C. es, entre otros, el de la persuasión:

\footnotetext{
${ }^{3}$ Vianello 2007, pp. LIX-LXIII.

${ }^{4}$ Lombardo 2008, p. 55.
} 
EuR.: No hay para la Persuasión otro espacio sagrado más que la palabra.

EsQ.: Entre los dioses, sólo la Muerte no gusta de dones.

Dio.: Suelten, suelten [los platillos]. De nuevo ha bajado más el de éste, pues colocó a la muerte, el más pesado de los males.

EuR.: Pero yo coloqué a la Persuasión, en un verso perfectamente bien expresado.

Dio.: La Persuasión es ligera y carece de sentido. Busca otro verso de peso completo, que incline la balanza hacia a ti, uno sólido y robusto. ${ }^{5}$

Si bien en este pasaje de Las ranas se hace mofa del peso de los versos de Esquilo y de Eurípides como si fuesen cualquier objeto que pudiera colocarse en una balanza, las alusiones de los contenidos no dejan de tener su propia validez e importancia. En un ambiente cultural como el ateniense del s. v a. C., donde la retórica ocupó un lugar primordial y fue una herramienta de primer orden en todos los saberes, conceptos como el aludido en Las ranas tenían una meridiana intención crítica. En efecto, la persuasión es un principio clave en la retórica aristotélica, pues su definición abarca tanto los procedimientos de la argumentación como el fin mismo de esta techne. En este sentido, la disposición argumentativa juega un papel esencial en la persuasión, pues a partir de la verosimilitud de sus componentes es que se puede lograr una determinada intención en el receptor. Lo que busca la retórica como cuestión concreta de sus procedimientos es disponer adecuadamente los medios de la persuasión. Dicha convicción no es otra cosa que lograr que el receptor sea "movido" por la palabra. El verso de Eurípides no es menos elocuente que el de Esquilo, pero lo que, según Lombardo, ${ }^{6}$ está expuesto en Las ranas es "la confrontación [...] en términos de una estética de la producción literaria como de una estética de la recepción: los dos dramaturgos ilustran sus respectivas técnicas [...] y explican los objetivos de su poesía”. Y por esta vía exegética es que Eurípides refleja cierto interés por la persuasión de la palabra en tanto que elemento estrictamente retórico y, más ampliamente, del quid de la tragedia.

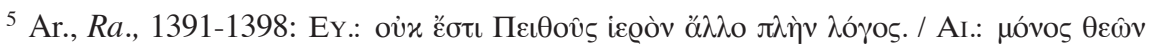

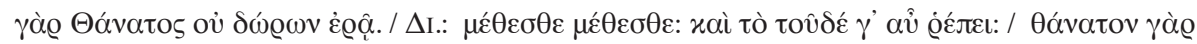

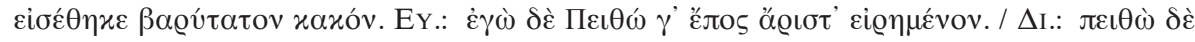

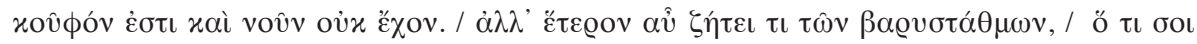

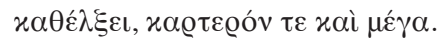

${ }^{6}$ Lombardo 2008, pp. 48-49. 
De modo semejante a lo expresado en la Retórica, Aristóteles afirma en la Poética que la tragedia debía de provocar en el receptor un movimiento de sus pasiones. Y el poeta debía hacer tal tarea utilizando sólo la palabra. Tanto en la Poética como en la Retórica, ${ }^{7}$ el Estagirita le otorga una menor importancia al asunto del espectáculo (ö $\psi \iota \varsigma)$ y, al contrario, le da un mayor énfasis a las posibilidades persuasivas de la palabra. Si se lleva este juicio retórico al ámbito de la poética, el movimiento mayúsculo que se provoca-

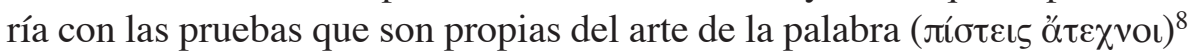
es la catarsis, esto es, la purificación a través de las emociones y de las pasiones. La catarsis es tanto una situación que explica cómo el sujeto se encuentra en un estado de purificación, así como un camino por el que, desde el plano literario, se puede llegar a una comprensión del logos que sería capaz de lograr que el individuo sea curado. Es por ello que si en el centro de la actividad retórica se encuentra "el cuerpo de la persuasión", entonces se comprende la correlación que guarda con la dialéctica, techne que considera las viabilidades de persuasión, de la misma manera que la medicina que, antes de curar, contempla las posibilidades de curación. ${ }^{9}$

Sabido es que para los griegos la palabra curaba o enfermaba, dependiendo del uso que de ella se hacía. De acuerdo con López Eire, Gorgias, alumno de Empédocles, perfiló como modelo de discurso persuasivo algo análogo al ensalmo que, al igual que el phármakon, seduce y modifica el alma de los oyentes. ${ }^{10}$ La psicagogía fue el "punto concreto" en el que coincidieron "Sofistas y no Sofistas, pues en la única modalidad de Retórica que admite el Divino Filósofo [...] lo psicológico desempeña un destacadísimo papel". ${ }^{11}$ Así, magia, medicina y psicología acuden puntualmente al crisol del lenguaje para crear mensajes persuasivos. Si esto es así, se puede dilucidar por qué la retórica busca los medios pertinentes de la persuasión, cuestión que se aclara a través de la analogía con la medicina que traza Aristóteles: "no es propio de la medicina el producir la salud, sino dirigirse a ese fin hasta donde sea posible", ${ }^{12}$ del mismo modo que del rétor no es propio lograr la persuasión en sí en el oyente, pero sí es su tarea

${ }^{7}$ Po., 1450b 17-19; Rhet., 1355b 55 y ss., y 1357a 21 y ss.

${ }^{8}$ Rhet., 1355b 35-39.

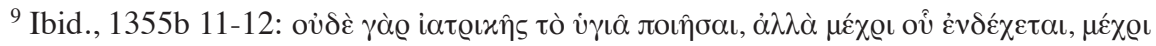

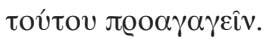

${ }^{10}$ López Eire 2005, pp. 115-119.

${ }^{11}$ Ibid., p. 127; cf. pp. 126-131.

${ }^{12}$ Ar., Rhet., 1355b 12-14. 
trazar los mejores argumentos, con las palabras adecuadas y el momento oportuno para lograr que aquél sea "movido" en sus pasiones, en su carácter, en su mismo pensamiento y actúe bajo esa consecuencia.

Esta aclaración de Aristóteles no contradice el hecho de que la finalidad de la retórica en sí sea la persuasión. Antes bien, tal delimitación obedece al carácter subjetivo que dicho procedimiento presenta, pues la retórica

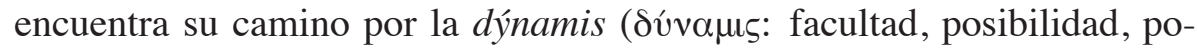
tencia) de "teorizar lo que es adecuado en cada caso para convencer". ${ }^{13} \mathrm{Tal}$ dýnamis es un concepto que marca la frontera con el sentido de la techne y que introduce la subjetividad del texto literario en tanto que depende de una "facultad" propia del emisor. En efecto, el rétor posee, entonces, la capacidad de crear la teoría sobre la argumentación o los argumentos, y no alguien que en sí y por sí pueda lograr la persuasión, pues dicho efecto persuasivo es palmario de acuerdo con el modo en que se presenta el orador y la actitud que toma el auditorio frente a éste. ${ }^{14}$ Cope señala en su introducción a la Retórica que esta definición aristotélica acerca de la dýnamis en el marco de este tratado se engarza con los principios de la teoría que trabaja con causas y efectos, en tanto que techne, y, por ello, guarda relación con la episteme que se aboca a los universales y las causas necesarias. ${ }^{15}$ Siendo esto así, el procedimiento filosófico de Aristóteles sobre la retórica permite observar que la persuasión está en cierto sentido enraizada en la lógica bajo el concepto de "lo probable": lo persuasivo ( $\left.\pi \bullet \alpha v v^{\prime} v\right)$ tiene efecto en la medida en que se basa en los probables y sus postulados son igualmente factibles.

Así, se puede afirmar que la retórica, por una parte, acude a la lógica para elaborar las estructuras argumentativas y, por otra, se sirve de la poética para establecer tanto formas como temas y tópicos que se refieren al aspecto estético del orden de las palabras. Una de las pautas a seguir en el análisis de los argumentos lógicos es su pertinencia en el texto literario: ¿cómo se corresponde el armazón lógico de las formas argumentales con la estética literaria? Esta pregunta se podría responder desde varias perspectivas, tomando en cuenta, también, algunos modelos específicos de la argumentación.

Quizá resulte obvio decir que en el análisis de un texto literario se puede llevar a cabo un estudio de la persuasión desde el terreno de la lógica. Tam-

\footnotetext{
${ }^{13}$ Ibid., 1355b 25-26.

${ }^{14}$ Ibid., 1377b 25-29.

${ }^{15}$ Cope 1897 , pp. 33-34.
} 
bién se puede hacer lo mismo al tomar sólo en cuenta el aspecto poético del texto. Sin embargo, hay una lectura más que es posible construir a partir del descubrimiento de ambos aspectos al momento en el que se cruzan en el maderamen del texto literario. Este procedimiento busca en la práctica evitar lo que ya Ricoeur señalaba como una de las causas de que la retórica haya sido durante mucho tiempo una "disciplina muerta y mutilada": ${ }^{16}$ recuperar el nexo que unía a la retórica y a la filosofía (la estética literaria).

Ahora bien, el término dýnamis se encuentra expuesto igualmente en la Poética y, además de la poesía propiamente dicha, se halla en el vocabulario filosófico. Según García Yebra, la "potencia" en la poética debe entenderse en el sentido que "Aristóteles atribuye a dýnamis en Metaf. V 12, 1019a23: $[\ldots]<<$ la potencia de terminar una cosa bien o según designio $>>$ ". ${ }^{17} \mathrm{Si}$ bien esta definición condesciende una capacidad creadora que persigue un fin totalmente acabado, parecería adecuado observar dicha capacidad tanto en el plano creador como en los efectos que conlleva en el receptor. Por principio, cada especie o género de la poética presenta su específica dýnamis; así, la "potencia" de la tragedia es la de provocar un placer particular a través de la imitación de acciones que causan en el espectador temor y compasión. Al hablar del objeto de la deliberación, Aristóteles menciona entre los tópicos de lo bueno "la habilidad para hablar y actuar" como causa productora de bienes $;^{18}$ de igual forma, en su Política, el filósofo indica que una cualidad del gobernante debe ser la gran capacidad para realizar las tareas del gobierno, ${ }^{19}$ es decir, para la buena administración. Como se puede observar, en los tres casos se habla de una capacidad natural en el sujeto para hablar, para actuar y para gobernar. Y no sería extraño que quien posee la capacidad de hablar pueda, en consecuencia, llevar a cabo actos entre los que se incluye el de gobernar: las tres acciones son consecuentes, y si bien unas y otras no se siguen necesariamente, se deducen entre sí. En el específico caso de la Poética, tal dýnamis, si bien hace alusión a los tres géneros de la poesía, se presenta como característica propia del poeta, del mismo modo en el que se atribuye al rétor una cualidad de persuasión que parte de su ethos. Es decir, cabe considerar que la dýnamis es componente del ethos tanto del poeta como del rétor.

\footnotetext{
${ }^{16}$ Ricoeur 2001, p. 15.

${ }^{17}$ García Yebra 1999, p. 243.

${ }^{18}$ Ar., Rhet., 1362b p. 22.

${ }^{19}$ Ar., Pol., 1309a 35.
} 
Esto es por lo que concierne al procedimiento del que crea el mensaje. Por otro lado, la dýnamis sólo puede ser comprobada, en cierto sentido, si hay una respuesta por parte del receptor, esto es, si éste es persuadido o si manifiesta algún sentimiento o pasión provocada por el mensaje. Si lo anterior es así, la dýnamis literalmente es la potencia que reside per se en la palabra lanzada por el emisor, y es activada por la capacidad del receptor. En la medida en que éste exprese tal o cual acción o pasión impulsado por el logos, es entonces que se puede determinar la presencia de la persuasión y, en mayor grado, de la catarsis.

Un ejemplo de lo anterior se encuentra en el diálogo Ion, donde Platón explica la relación entre emisor y receptor a partir de la dýnamis y las reacciones que ésta puede provocar. Ion es un poeta cuyos versos nada tienen que ver con la techne ${ }^{20}$ él puede recitar los versos de Homero como resultado de una théia dýnamis. La divinidad posee e inspira al poeta, es decir, él es poseído y poseedor de la dýnamis divina, misma que transmite a sus oyentes. Platón hace explicar esta idea a Sócrates con la imagen de la piedra de Heraclea: el impulso que la Musa transfiere al poeta es como la fuerza de un imán, que atraerá a otros poetas (Orfeo, Museo y Homero inspirados por las Musas que a su vez son fuente de inspiración), formando así una larga cadena de anillos imantados; el poder magnético de la Musa alcanza a quien escucha los versos que inspira, por ello el receptor pasa a ser parte también de la cadena imantada, esto es, de una tradición poética. Así, las palabras del poeta, de acuerdo con la potencialidad de sus versos, son imanes que, a su vez, atraen al receptor a partir de las intenciones persuasivas y catárticas.

Partiendo de la transmisión del entusiasmo poético "movido" por una dýnamis, habría plena concordancia entre la retórica aristotélica, el diálogo platónico y el tratado De lo sublime, pues el fondo y la forma son elementos esenciales en el equilibrio del texto, esto es, "la experiencia de la invención, así como el orden y la economía de las materias". Heuresis, taxis y los temas como elementos de composición retórica, "se ven manifestarse arduamente a través de toda la trama del discurso", ${ }^{21}$ aseveración que ya se encuentra antes en la retórica aristotélica con los términos de

${ }^{20} \mathrm{Pl}$., Ion, 533d-e, 535e, 536b.

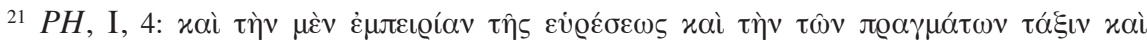

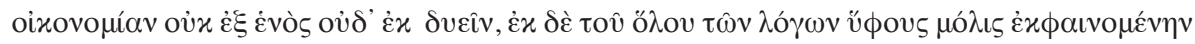

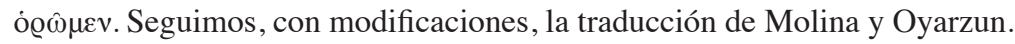


próthesis y pistis..$^{22}$ Esto indica que el discurso está sostenido con tales ejes que se entrecruzan continuamente, lo que da como resultado el textum. Pero lo sublime sólo aparece cuando la potencia del orador (

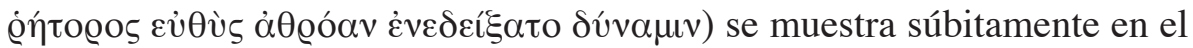

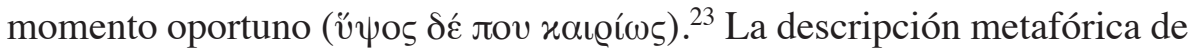
Pseudo Longino es elocuente en tanto que trata de explicar cómo a lo largo de un texto de buena urdimbre es posible que el lector encuentre momentos en los que la potencia del escritor se hace evidente como fórmula que se resuelve por sí misma bajo los ojos del receptor, al punto de que éste podría padecer lo sublime.

Ahora bien, tal padecimiento de lo sublime ya está expresado de cierta manera en Las ranas y es un ejemplo útil para entender, luego, a Pseudo Longino. En efecto, Aristófanes hace exponer a Esquilo las cualidades de un estilo grandioso y elevado que es antecedente del concepto clave de la teoría del De lo sublime: "es necesario dar a luz palabras en consonancia con las grandes ideas y pensamientos. En todo caso, de los semidioses es propio que usen palabras de mayor presencia, pues del mismo modo llevan mantos mucho más solemnes que nosotros". ${ }^{24}$ La ecuación es aparentemente sencilla: lo que en el pensamiento es elevado no puede ser expresado más que con palabras (rhémata) que designen cabalmente aquello que existe como imagen mental y que guarda la misma estatura. Esta concordancia es tarea del poeta. La analogía es elocuente por demás: las palabras se adecuan al pensamiento, como la vestimenta al cuerpo de los héroes. Éstos sólo podrían llevar encima ropajes que revelen su particular carácter y naturaleza. En palabras de Pseudo Longino: "lo sublime es el eco de la grandeza de pensamiento. De ahí que a veces sin sonido un pensamiento desnudo, reducido a sí mismo, suscita admiración por la grandeza de su significado". ${ }^{25}$ Además, entre los cuatro componentes indicados debe existir un equilibrio. En efecto, esta imagen expuesta por Aristófanes y la idea del De lo sublime bien pueden compararse, a su vez, con las observaciones que Aristóteles establece en la Poética en torno a las particularidades de

${ }^{22}$ Rhet., $1414 \mathrm{~b} 8-9$.

${ }^{23} \mathrm{PH}, \mathrm{I}, 4$.

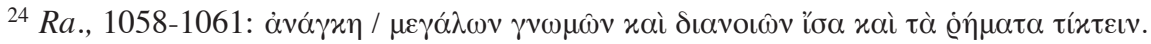

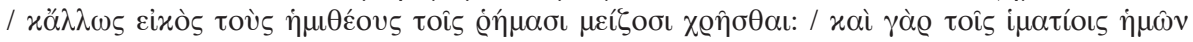

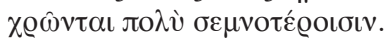

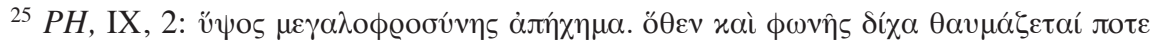

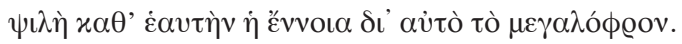


los caracteres, ${ }^{26}$ de donde se colige que hay una adecuación del personaje en cuanto a su naturaleza con su modo de presentarse, sobre todo a través de sus palabras.

Volviendo al ejemplo tomado de Aristófanes, se puede indicar que el estilo sublime que define a Esquilo se opone a lo que habría buscado Eurípides: una poesía más simple en términos del lenguaje, pero al mismo tiempo más intelectual. Y en este punto contradictorio se halla también la razón en torno a la persuasión: si Esquilo busca persuadir, lo hace "impre-

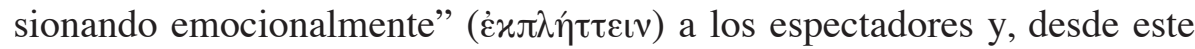
golpe dirigido al ethos y al pathos, ${ }^{27}$ se puede arribar al ideal de hacer mejores ciudadanos mediante la poesía; si Eurípides habla de persuasión y busca persuadir, lo hace a través de una argumentación que conduce al refinamiento intelectual, esto es, la persuasión como concepto retórico y, en tanto tal, objeto de una argumentación; en consecuencia el golpe emocional queda en segundo término.

En efecto, una explicación más de los resultados poéticos se encuentra contenida en el concepto de lo sublime, esto es, aquel pasaje específico del texto literario que logra colocar al receptor en una situación tal, que únicamente puede ser entendida como una elevación, un padecimiento de lo excelso, es decir, de aquello que se aprecia "como cierta cúspide y excelencia del discurso y que los más grandes poetas y escritores sólo por este medio alcanzaron la preeminencia y la inmortalidad de su reputación", se-

${ }^{26}$ Po., 1454a 16-1454b 18.

${ }^{27}$ Se debe de hacer una distinción de ambos puntos de llegada de la persuasión, pues la recepción y el "movimiento" que se crea en cada uno de ellos, ethos y pathos, difiere. Quintiliano, VI, 2 8-9, diferencia claramente estos conceptos: "8. sicut antiquitus traditum accepimus, duae sunt species: alteram Graeci jó $\theta$ os vocant, quod nos vertentes recte ac proprie adfectum dicimus, alteram ${ }^{5} \mathrm{H} \theta$ os cuius nomine, ut ego quidem sentio, caret sermo

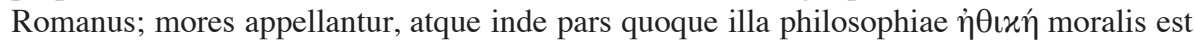
dicta. 9. Sed ipsam rei naturam spectanti mihi non tam mores significari videntur quam morum quaedam proprietas; nam ipsis quidem omnis habitus mentis continetur. cautiores voluntatem complecti quam nomina interpretari maluerunt. adfectus igitur Já $\theta$ o ऽ concitatos, 'H $\mathrm{H} \theta$ o mites atque compositos esse dixerunt; in altero vehementer commotos, in altero lenes; denique hos imperare, illos persuadere; hos ad perturbationem, illos ad benivolentiam praevalere. adiiciunt quidam? ${ }^{3} \mathrm{H} \theta$ o s perpetuum, $\pi$ ó $\theta$ os temporale esse. quod ut accidere frequentius fateor, ita nonnullas credo esse materias, quae continuum desiderent adfectum. nec tamen minus artis aut usus hi leniores habent, virium atque impetus non tantundem exigunt. In causis vero etiam pluribus versantur, immo secundum quendam intellectum in omnibus". 
gún Pseudo Longino. ${ }^{28}$ En el marco del logos, entendido en De lo sublime como discurso en general, i. e. el texto literario, se hallarán momentos que se aprecien como elevaciones de notoria consideración, en virtud de que esos pasajes son los que prueban lo trascendental del escritor y su obra. De lo anterior se derivan dos reflexiones:

1) Es en los lugares de lo sublime en donde se puede establecer también que reside la dýnamis. Si hay una capacidad de hablar, y por extensión de escribir, que está orientada a buscar los medios de la persuasión, entonces cuando tal objetivo se logra es lícito admitir que también se está en posibilidad de alcanzar un plano superior en las impresiones de la creación literaria,

en efecto, - dice Pseudo Longino - no es a la persuasión de los que escuchan, sino al éxtasis que lleva lo prodigioso; lo asombroso, junto con aquello que embelesa, siempre prevalece por doquier sobre lo persuasivo y gracioso, pues lo persuasivo depende mayormente de nosotros, y en cambio aquellos ejercen un poder y una violencia irresistibles; sobrepujando al que oye completamente. ${ }^{29}$

Siguiendo esta explicación de Pseudo Longino, lo sublime es un resultado más allá de la persuasión, en un plano en el que se aprecian distintos niveles de recepción e impresión del logos, pues la finalidad de lo persuasivo es lo inmediato, lo pragmático, cualidades que si bien están presentes en el texto literario en general, guardan la naturaleza argumentativa propia de su objeto: el discurso. En cambio, lo sublime, para ser tal, debe trascender en tanto que es comprensión y padecimiento que no depende de la voluntad del receptor, sino que, volviendo a Gorgias, se comprende que

la palabra es un poderoso soberano que, con un cuerpo muy pequeño y por completo invisible lleva a cabo obras sumamente divinas. Puede, por ejemplo,

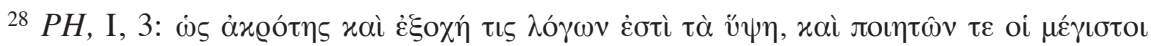

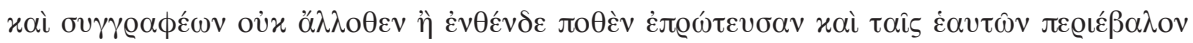

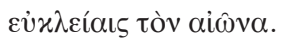

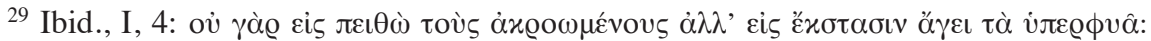

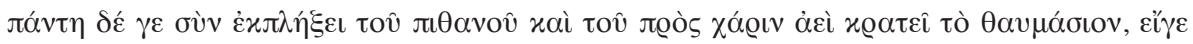

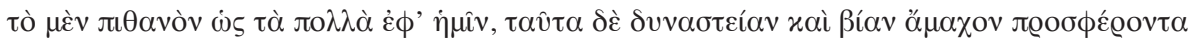

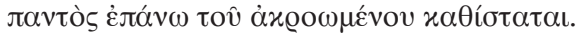


acabar con el miedo, desterrar la aflicción, producir la alegría o intensificar la compasión. ${ }^{30}$

Se trata, entonces, de la palabra seleccionada retórica y estéticamente

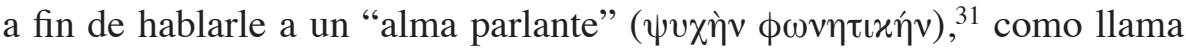
Pseudo Longino a la parte más interna del receptor que se persuade y se regocija o padece de ella. Retórica, porque se puede corresponder con lo que Aristóteles recomienda sobre el uso de "términos útiles para la expresión

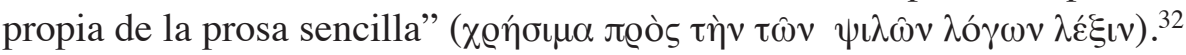
Estética, porque se trata de una discriminación de términos justos y eleva-

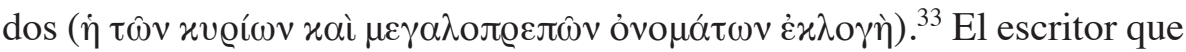
busca lo sublime recoge las palabras que tienen la propiedad y la grandeza de lo que quiere transmitir, lo que no se opone a la sencillez como cualidad retórica que indica Aristóteles, y también Eurípides, según Aristófanes en Las ranas, como ya vimos.

La composición del texto literario a partir de esta selección de términos ocurre como tarea de la retórica para hacer efectivo el argumento persuasivo, de ahí el carácter pragmático del discurso que puede ser verosímil, pero no trascendental si se piensa en lo sublime. Un ejemplo de ello es el final del Contra Eratóstenes de Lisias: "han escuchado, visto, padecido. Lo

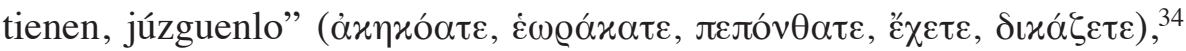
que como parte del epílogo sintetiza en cinco sintagmas en asíndeton lo que compete a una práctica retórica. El orador ya habló, es decir, argumentó, los jueces oyeron y, por lo tanto, están en posibilidad de juzgar. Y esta acción se corresponde con la persuasión a través del esperable padecimiento que las palabras del orador habrían provocado en los oyentes. Así, la dýnamis del discurso habría cumplido su cometido persuasivo. En cambio, lo sublime es lo trascendental, pues Pseudo Longino afirma que "la belleza evidentemente sublime es aquella que agrada siempre y a todos" ${ }^{35}$ Lo persuasivo no necesariamente agrada al oyente, lo sublime sí. Y lo es porque, para expresarlo de manera simple, pasa la prueba del tiempo. En efecto, es lícito decir que en el $\mathrm{PH}$ el término aión adjetiva el texto que a causa de

\footnotetext{
${ }^{30}$ Gorg., Helen., 8.

${ }^{31} \mathrm{PH}, \mathrm{XXX}, 1$.

${ }^{32}$ Ar., Rhet., 1404b 30.

${ }^{33} \mathrm{PH}, \mathrm{XXX}, 1$.

${ }^{34}$ Lys., XII, 100.

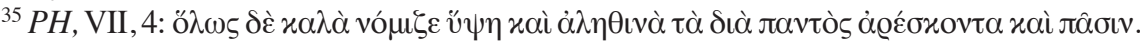


ser trascendental, como sucede con los casos de Homero, Demóstenes y Platón, entre otros,

a causa de ello, toda la posteridad y la vida, que no pueden ser contenidas por la paranoica envidia a delirar, a aquéllos les concedieron el premio de la victoria e incluso ahora vigilan para que nadie se los despoje y continuar, así, conservándolos. ${ }^{36}$

Aión, lo eterno o la posterioridad, es también el juicio sobre el texto literario que transita de generación en generación y, por lo mismo, se convierte en un modelo literario. Y esto sólo sucede cuando el texto se activa, pues la eternidad no puede ser mera potencia, sino la revelación de lo que acontece a través del tiempo cuando se acciona el logos; así lo experimenta y comenta el Pseudo Longino respecto de poetas como Homero o rétores como Demóstenes, a quienes se refiere en la cita anterior a modo de ejemplos de lo que implica el término aión. ${ }^{37}$

Hay que subrayar que mientras Aristóteles hace depender del rétor la capacidad persuasiva, el De lo sublime, por su parte, indica textualmente que

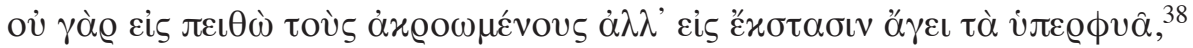
es decir, que la persuasión es una cuestión que compete al auditorio, en oposición, según se colige, al éxtasis. No obstante esto,

en virtud de que a toda cosa están asociados naturalmente una serie de elementos compatibles con la materia de cada una, es necesario que para nosotros la causa de lo sublime pueda ser la capacidad de elegir siempre los componentes más importantes, y agrupándolos sucesivamente, formar como un solo cuerpo. ${ }^{39}$

La composición del texto es una tarea esencial de la techne del rétor y del poeta, pero para que este entramado sea comprensible y cumpla con los fines de la persuasión o del padecimiento de lo sublime, en el receptor

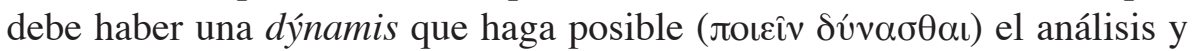

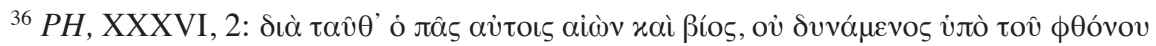

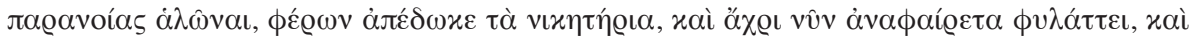

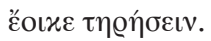

${ }^{37}$ Segal 1959, pp. 121-146.

${ }^{38} \mathrm{PH}, \mathrm{I}, 4$.

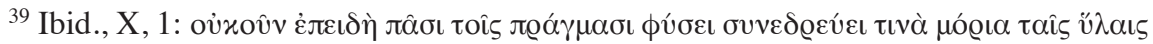

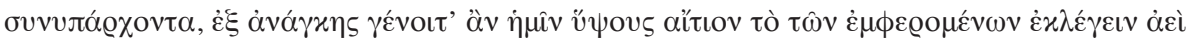

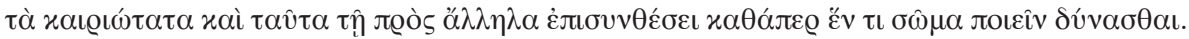


la síntesis del mismo en un único proceso de selección, una suerte de criba que deja sólo aquello que trasciende por ser sublime.

2) Cabe sugerir que lo sublime, concepto ya afianzado en una cultura que habla de escritor con todas las implicaciones que esto conlleva, es el equivalente de la catarsis. Quizá el hecho no menor de una sociedad con una tradición marcadamente oral como la que vio el origen y el desarrollo de la retórica fuera común hablar de persuasión. Es decir, hay que comprender la persuasión como un proceso propio de la oralidad y del discurso; en tanto que en una sociedad donde ya hay escritores y lectores, y la oralidad, si bien está presente, es un recurso en cierto modo secundario, se recurre a conceptos como los que plantea Pseudo Longino para entender la creación y recepción del texto. Así, siguiendo el De lo sublime, se puede afirmar que el lector experimenta a través del texto literario una transformación mediante la cual se coloca fuera de sí ('̌x $\chi-\sigma \tau \alpha \sigma \iota \varsigma)$, lo cual se comprueba en un agrandamiento del individuo ( hace recordar las Nubes de Aristófanes, v. 76) y que por extensión refiere lo monstruoso, lo extraordinario, lo extremadamente curioso.

Pongamos lo anterior frente a la Poética: Aristóteles menciona dos tipos de poetas, unos que poseen talento y que se amoldan bien a las situaciones,

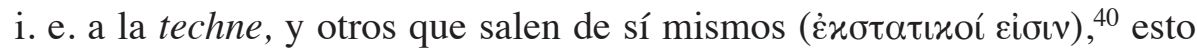
es, poetas extáticos, aquellos que se ponen en trance de creación poética. En el Ion (533e-534a), Platón habla específicamente de este último caso de capacidad creadora que se basa en el "entusiasmo" o arrebato que padece el poeta por intervención divina, hecho que ya apuntábamos al principio de este trabajo. Asimismo, en la Apología (22b-c), Platón hace decir a Sócrates que los poetas crean gracias a cierta disposición natural y arrebatados

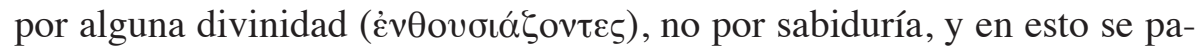
recen a los adivinos y a los profetas, quienes, al igual que el poeta, pueden decir cosas bellas, pero no saber nada de lo que dicen. Así pues, si el creador lleva a cabo su composición fuera de sí, esta cualidad se comparte con el receptor, quien padecerá el éxtasis por contagio, por mímesis, porque la palabra se inocula en él para hacerle percibir el abandono de sí y su consiguiente elevación. De hecho, en el mismo pasaje aludido de la Poética, Aristóteles hace explícita esta relación empática entre el poeta y el espectador, mediando entre ellos el texto poético, pues habla de una naturaleza propia de aquel que logra persuadir con mayor profundidad si está inmerso

${ }^{40}$ Po., 1455a 32-35. 
en las pasiones, esto es, si lo que dice poéticamente está estructurado de manera tal que pueda hacer sentir la agitación y la ira. ${ }^{41}$ Siendo esto así, la persuasión es de modo simple el equivalente de lo sublime, cruzando el proceso del éxtasis que guarda relación a su vez con la catarsis. Nuevamente, es Platón en su Ion (535c) quien ejemplifica lo antedicho: "Cuando yo recito algo emocionante ( $\dot{\lambda} \lambda \varepsilon \iota v o ́ v)$ se me llenan los ojos de lágrimas; si

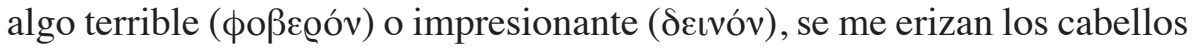
y palpita mi corazón”. Así, inmerso totalmente en la situación poética, Ion motiva en sí mismo y para quienes lo escuchan la compasión y el miedo, estados de ánimo que son connaturales de la catarsis.

En efecto, la animación poética de la compasión y del miedo comporta una terapia a través de la simulación puesta en el teatro que experimenta el sujeto que se mira a sí mismo ajeno de los terribles mitos puestos en acción:

el espectador experimenta no sólo la transposición filantrópica de quien se identifica sin dudarlo con los luctuosos casos de los personajes, sino también la autocomplacencia egocéntrica de quien, después de un estado de sufrida identificación, constata con alivio la diferencia entre verdadero dolor y la mímesis dramática. ${ }^{42}$

Si bien en cada uno de los conceptos revisados hasta ahora parece que la experimentación que vive el sujeto a partir de la palabra poética y retórica es semejante a la curación que se da por medios extáticos, también hay que considerar que la capacidad creadora es la que determina un sentido estético, persuasivo y trascendental que vincula al ser humano con el universo, mediando la palabra que al nombrar da la existencia a todo, gracias a la savia que hace palpitar a quienes comprenden su sentido.

Vale la pena señalar que con estos conceptos, como se ha apuntado con brevedad, se cuenta con un mecanismo que da como resultado la conformación de un canon literario:

En general, considera cumplida y verdaderamente sublime aquello que complace a todos en todo tiempo. En efecto, cuando personas que difieren en sus quehaceres, formas de vida, gustos, edades y modos de pensar, coinciden en opinión sobre una misma cosa, entonces este juicio y aquiescencia coincidente

\footnotetext{
${ }^{41}$ Po., 1455a 29-33.

${ }^{42}$ Lombardo 2008, p. 115.
} 
a partir de tal diversidad confiere una prueba fuerte e incuestionable a lo que se admira. ${ }^{43}$

Lo anterior también se colige en lo siguiente:

Este varón [sc. Platón, a propósito de la República] nos muestra [...] otro camino que lleva hacia lo sublime. ¿Cómo y cuál es? La imitación y la emulación de los grandes escritores y poetas pretéritos. ${ }^{44}$

Pues se cumple con ese repertorio sustentado por el tiempo lo que Aristófanes expone en Las ranas sobre la tarea suprema de la poesía: hacer mejores ciudadanos para la polis y que Pseudo Longino sintetiza así:

En efecto, al presentarse ante nosotros esos magníficos personajes como modelos de emulación, guiarán de alguna manera, como antorchas, nuestra alma hacia las medidas ideales de perfección. ${ }^{45}$

Los tratados aristotélicos vinculados con el lenguaje (Retórica, Poética y en menor medida algunos conceptos del Perí hermeneías y de los Analíticos), así como su estructura retórica y poética y sus alcances estéticos y lógico-interpretativos demuestran que los mecanismos de la argumentación y de la construcción de la figura retórica son procesos comunes a la persuasión que se busca generar en los receptores. Por esta razón, se puede pensar que ambos armazones son correlativos, tanto en la manera de su cimentación como en los fines propios de la persuasión. La retórica definida por Gorgias como artesana de la persuasión, brinda indicios del sentido técnico que existe en la composición del texto literario: hay una capacidad creativa capaz de elaborar estrategias del lenguaje que persuaden al receptor. Hay que considerar a la persuasión como un paso previo a la catarsis. Si en primer término no hay un movimiento de las pasiones, de las emociones y/o

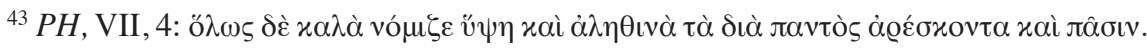

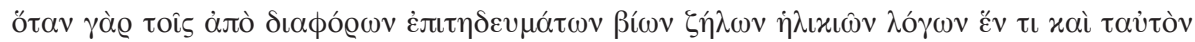

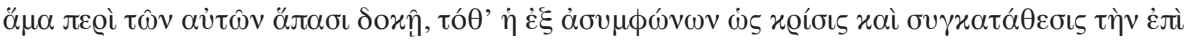

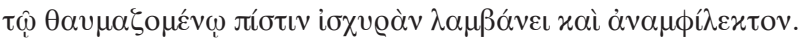

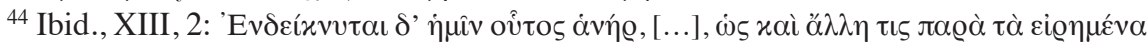

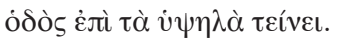

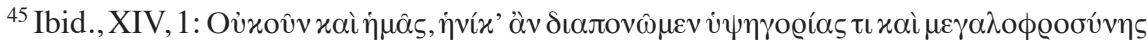

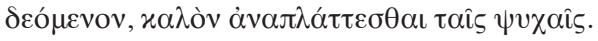


del pensamiento, no se puede aspirar a lograr que el individuo experimente por medio de la empatía que trasmite la palabra una purificación, una dosis médica que se dirige a los tres puntos de recepción indicados: ethos, pathos y logos. De esto se sigue, como afirma Saint Girons, ${ }^{46}$ la metamorfosis del receptor, pues el conocimiento que ofrece lo sublime, la persuasión y lo catártico indefectiblemente modifica la naturaleza del ser. Y de semejante modo, la catarsis es o bien una circunstancia semejante a la experimentación de lo sublime (salir de sí, elevarse de sí para ser tocado por los dones de la palabra), o bien es un paso previo a este padecimiento, en tanto que el De lo sublime involucra además la discriminación de aquello con lo que se persuade al alma y al intelecto.

\section{BIBLIOGRAFÍA}

ARISTÓFANES, Ranas, introducción, comentario y traducción de José García López, Murcia, Universidad de Murcia, 1993.

Aristophane, Les Thesmophories, Les Grenouilles, t. IV, edición de Victor Coulon, traducción de Hilaire van Daele, Paris, Les Belles Lettres, 2012 (1928).

ARISTÓTELES, Retórica, introducción, traducción y notas de Quintín Racionero, Madrid, Gredos, 1990.

_, Rhétorique, 3 vols., edición y traducción de Mérédic Dufour y A. Wartelle, Paris, Les Belles Lettres, 1973 (1960).

_, Poética, edición trilingüe de Valentín García Yebra, Madrid, Gredos, 1999 (1974).

Cope, E. M., An Introduction to Aristotle's Rhetoric with Analysis notes and Appendices, London and Cambridge, Macmillan, 1897.

Diels, H. \& W. KRANZ (eds.), Die Fragmente der Vorsokratiker, Berlin, Weidman, 1952.

Dionysio Longino, Libellus de sublimitate, edición de D. A. Russell, Oxford, Oxford University Press, 1981 (1968).

_, On the Sublime, edición de W. Rhys Roberts, Cambridge, Cambridge University Press, 2011 (1907).

García Yebra, Valentín, véase Aristóteles.

Hesíodo, Teogonía, introducción, traducción y notas de Paola Vianello, México, Universidad Nacional Autónoma de México, 2007 (1978).

${ }^{46}$ Saint Girons 2008, pp. 23-24: "Lo sublime es un principio de metamorfosis, al menos cuanto lo es de conocimiento. Más aún, su saber me modifica íntimamente, incluso antes de que yo haya tenido acceso a él, mientras que, por el contrario, el mero conocimiento, permanece externo a mí. Páthei máthos, <<en el sufrimiento existe el conocimiento>>, canta un coro del Agamenón de Esquilo (v. 177): el auténtico saber descansa sobre la prueba y no evita ninguno de sus dolorosos aspectos". 
Lombardo, Giovanni, La estética antigua, Madrid, A. Machado Libros, 2008 (2002). LÓPEZ EIRE, Antonio, Sobre el carácter retórico del lenguaje y de cómo los antiguos griegos lo descubrieron, México, Universidad Nacional Autónoma de MéxicoInstituto de Investigaciones Filológicas, 2005 (Colección Bitácora de Retórica, 21).

OKSENBerg Rorty, Amelie (ed.), Essays on Aristotle's Rhetoric, Berkeley \& Los Angeles, University of California Press, 1996.

Platon, Oeuvres complètes: Ion, Ménexène, Euthydème, vol. V, edición y traducción de Louis Meridier, Paris, Les Belles Lettres, 1931.

Ps. Longino, De lo sublime, traducción de Eduardo Molina y Pablo Oyarzun, notas e índices de Pablo Oyarzun, Santiago de Chile, Ediciones Metales Pesados, 2007.

Quintilien, Institution oratoire, t. IV, edición y traducción de J. Cousin, Paris, Les Belles Lettres, 1976.

Ricoeur, Paul, La metáfora viva, Madrid, Trotta, 2001.

Saint Girons, Baldine, Lo sublime, Madrid, A. Machado Libros, 2008 (2006).

Segal, Ch. P., "Hypsos and the Problem of Cultural Decline in De Sublimitate", HSCPh, 44, 1959, pp. 121-146.

Vianello, Paola, 2007, véase Hesíodo. 
